\title{
Developing School Management Model Based on Balinese Local Wisdom
}

\author{
A.A. Gede Agung ${ }^{1}$, I Gusti Putu Sudiarta ${ }^{2}$ \\ Dept. of Educatinal Technology, Dept. Mathematics Education \\ Ganesha University of Education \\ Singaraja, Indonesia \\ agung2056@yahoo.co.id ${ }^{1}$, gussudiarta@undiksha.ac.id ${ }^{2}$
}

\begin{abstract}
The multidimensional disharmony, such as various kinds of violence still occur in our schools today. The subjects were not only students but also teachers, principals, employees, even parents. Several approaches have been tried to solve this problem. A legal approach such as Permendikbud 82/2015 had been issued by the Indonesian Minister of Education and Culture to regulate the prevention and countermeasures of violence in education. It had even been also proposed for schools to create a violence prevention task force. From all of these approaches, neither holistic, systemic, and systematic approach based on comprehensive pedagogical foundations, nor strong local wisdom concept has been adopted in school management practices. The purpose of this article is to describe a school management model based on balinese local wisdom and culture in order to build character, culture, and harmony in the school. Some principles and concepts of balinese local wisdom and culture was proposed to serve as the foundation of school management model.
\end{abstract}

Keywords-School Based Management, School Culture, Character, Local Wisdom, Balinese Culture

\section{INTRODUCTION}

Violence in schools involves not only students but also teachers, employees, even parents. The recent facts in Indonesia, around April-May 2016 show that there has been or has just been uncovered dozens of cases of violence, such as sexual violence that involved school children. Often shown on television shows, as well as news in print and online newspapers, about violence perpetrated by schoolchildren, ranging from cheating, brawls, and even other brutal actions. This is very far from the goal of the Indonesian education that is to build a complete intelligent man, pious and noble character.

This is, in fact, not a new phenomenon. Based on the results of research conducted by UNICEF [1] in several regions in Indonesia showed that about $80 \%$ of the violence that occurs in students were done by teachers. The examples of violence were throwing students with erasers and rulers, drying students in the field, and steaming students and so forth. In addition, students also experienced psychological violence in the form of scolding and insulting words. Cases of violence like these does not represent the role of a teacher as an educator or representation of parents in the school. Unfortunately, many teachers in Indonesia still believe that such kind of action is still effective to control students [2].
This can lead to psychological trauma or students will hold a grudge, increasingly immune to punishment, and tend to vent anger and aggression against other students who are considered weak. This negative circle, if continues, may perpetuate a culture of violence in society.

Schools, in this case, must take responsibility and stand at the forefront to control this social phenomenon. Strategic steps must be taken, from the strategy of the managerial system, the curricular and non-curricular systems, which are based on a comprehensive pedagogical concept that matures human beings. Of course, the school is not alone in handling this matter. At least, there are three parties which have important roles to grow children, School, Family and Society, Three centers of Educacion, Ki Hajar Dewantara [3]. In addition to school, the family should also have an active role. The family is the main place for children's education, after the school. Children will first get good or bad behavioral input from the family. If the family provides poor input, then the child tends to be less good as well. Conversely, if the family provides good education then the child will tend to be good too.

In addition to schools and families, the community also plays a huge role. What children get in the family and at school will be tested, compared, and modified, even changed, when they are in the community. The development of civilization and culture, especially since the rapid development of science and technology, has a lot of influence on the order of life of mankind. Some of this influence, of course, may be positive, and many are also negative. Family daily life too have been much changed. This change is often far from the true family values. In the current state of modernization and globalization, many people believe that people's lives, especially the life of the younger generation, are very worrying. All of this can take root and start from living conditions within the family itself. Therefore, early childhood coaching and education in the family is a very basic one. Here, the toughness of the family in filtering out the effects of both negative and positive is necessary. The school is the right environment to insert educational goals. Very relevant to the teachings of Ki Hajar Dewantara, education is an effort to promote the mind and body of children, in order to achieve perfection of life. Children' life must be in harmony with nature and society. While the Educational Law Number 20 Year 2003 [4] understands education as a conscious and planned effort to create an atmosphere of teaching and 
learning process, so that learners actively develop their potential, have spiritual strength, self-control, personality, intelligence, noble character, and skills needed by society, nation, and state.

Several approaches have been attempted to solve this problem, starting with the legal approach as issued by the Education and Culture Ministry through Permendikbud $82 / 2015$ [5] on the prevention and countermeasures of violence in the school. It is also proposed to schools creating a violence prevention task force. From all of these approaches, neither holistic, systemic and systematic approach based on comprehensive pedagogical foundations, nor strong local wisdom concept has been adopted in school management practices. Balinese Local wisdom (BLW) should be applied as a strong foundation to build human character and noble virtuous character. This seems to be acceptable in general because BLW has been proven to be applied by family and people of Bali since hereditary, although it cannot be separated from the changes and influences of the global age.

But what kind of BLW, and how far this BLW really can be applied in the context of school management, what its concrete contribution is, there seems to be no adequate literature and study on this matter. To date, no specific discourse has been discussed in the context of Modern School Management, yet no school has ever dared to declare itself in its vision as a school based on the BLW. This article will discuss (1) how to integrate the BLW with the concept of Modern School Management, (2) which types of BLW can be used as a foundation for developing a BLW- based School Management Model. This article is expected to give scientific contribution in developing school management based on the local wisdom of Bali that own a good and harmonious character as the main principle. That is a school as a place for honesty, tolerance, respect for differences, love for the environment, discipline, hard work, curiosity, and admiration.

\section{STUDY LITERATURE}

\section{A. Management and Organizational Culture According to Western Theory}

According to western theory perspectives, organizational culture refers to the norms of behavior, assumption, and belief of an organization. While organizational climate refers to the perceptions of people in organizations that reflect these norms, assumptions and beliefs. Creemers [6] states that "organizational culture is a pattern of beliefs and expectation shared by the organization's members". Also, Reynolds [7] state that organizational culture is the process of socializing members of the organization to develop perceptions, values, and beliefs towards the organization. On the other hand, Greenberg and Baron (1995 in [8] ) emphasizes organizational culture as a cognitive framework containing the attitudes, values, behavioral norms and expectations of members of the organization. Organizational culture includes beliefs, ideologies, languages, rituals, and myths. Finally, Creemers [6] concludes that organizational culture is the overall norms, values, beliefs, and assumptions held by members of the organization.

Based on the above explanation, it can be concluded that organizational culture is concerned with beliefs, assumptions, values, norms of behavior, ideology, attitudes, habits, and expectations held by the organization (in this case including private university organizations). Organizational culture is the organizational personality that affects the way individuals act in organizations. The function of organizational culture is: 1) giving a sense of identity to the members of the organization, 2) generating commitment to the mission of the organization, 3) guiding and establishing the standards of behavior of members of the organization and 4) improving the stability of social systems[6].

However, the components of Organizational Culture (School) can be described some of the following views:

a) Ebadollah [9] who cited the views of Deal and Kennedy (1990) puts forward the following key organizational attributes: 1) the values of shared beliefs and the philosophy of their members, 2) exemplary modeling heroes, members of organizations with the best personalities and strong cultural values Organizations, 3) rituals that are symbolic ceremonies to celebrate and strengthen the interpretation of organizational values, 4) cultural communication networks ie the channels of interaction used to introduce members to organizational culture.

b) Greenberg and Baron (1995, in [8]) suggest four characteristics of organizational culture: quality (everyone is responsible for achieving quality), responsibility (each employee is responsible for his actions and decisions), togetherness (creating situations where everyone can connect), efficiency (Organizational sustainability efficiently), and freedom (giving employees the opportunity to design their future).

c) Robbins [10] presents seven characteristics of organizational culture: 1) individual autonomy, namely the degree of freedom, responsibility and individual opportunity to take initiative in the organization, 2) the structure that is the level of regulation and accuracy used to control employee behavior, 3) support, i.e. the level of help and friendliness of managers to employees, 4) the identity of the member's familiarity with the organization as a whole, especially the information of the working group and its professional expertise, 5) performance prizes, namely the level of prize allocation based on employee performance criteria, 6) conflict tolerance, i.e. levels of conflict in peer relations and willingness to be honest and open to differences, and 7) risk tolerance, i.e. the level of encouragement of 
employees to aggressive,innovative and dare to bear the risk.

d) Hill, Ottem and DeRoche [11] present four characteristics of an effective organizational culture as follows: 1) structure and command, 2) support for social interaction, 3) support for intellectual or learning activities and 4) strong commitment to the mission and vision of the organization.

Based on some of the above views, it can be concluded that there are twelve characteristics of organizational culture, namely hero values, organization / exemplary, responsibility, togetherness/intimacy, individual autonomy, rules/norms, support, identity, reward performance, Risk tolerance and symbolic ceremonies.

\section{B. Relationship Between Leadership Style, Organizational Culture, Organizational Climate and Organizational Effectiveness}

The relationship between leadership style, organizational culture, organizational climate and organizational effectivenes has been explained by several authors, as follows:

a) Deshpande and Webster [12] state in relation to organizational effectiveness, there are several views and research results underlying this study. The beliefs and assumptions in the organization constitute organizational structures and processes, and affect attitudes, commitments and performance (Beliefs and assumptions are part of the organizational culture.) It can therefore be concluded that organizational culture affects organizational effectiveness.

b) Jamal [13] found that it is determined that principals with a moral value system lean more towards a transformational leadership style and principals with a pragmatic value system lean more towards a transactional leadership style.

c) Cheng [14] revealed that difference in organizational culture can be reflected at least in three overt levels: (1) organizational level in terms of principal's leadership behaviors, organizational formalization and participation, and teachers' social norms; (2) teachers' attitudinal level in terms of organizational commitment, social job satisfaction, intrinsic job satisfaction, and influence job satisfaction; and (3) school effectiveness level in terms of perceived overall organizational effectiveness and academic achievements in public examinations.

Based on the results of the research presented above, it can be concluded that organizational culture affects the effectiveness of the organization, including when viewed from the point of effectiveness of the organization process. Leadership style convincingly affects the culture of the group or organization. If the leader keeps distance with subordinates, then this attitude has a negative impact on the organization. Organizational culture is a consequence of transformational leadership. The essential function of leadership is to manipulate culture. Thus the role of the leader is very important in creating a strong organizational culture. A strong organizational culture is associated with strong leadership, participatory organizational structure, and positive social interaction. The behavior and attitude of managers or leaders influenced national culture. The organizational culture has a powerful influence on organizational climate development. Further explained that the organizational culture affects the attitude and feeling of self-belonging of the organization member. The view is reinforced by Kraft, Marinell and Yee [15] whose research suggest that to systematically improve student performance, school and district leaders need robust evidence about the strengths and weaknesses of both individual teachers and the school organization and culture as a whole. Equipped with this data, policymakers and practitioners can take steps to address individual as well as organizational strengths and deficiencies.

\section{DISCUSSION}

\section{A. Contex of the Discourse}

Since the last few decades, Indonesia has undergone reforms in all areas, including the reform of the National Education System. Some of the most prominent reforms were (a) the recognition of education as a national system (Law No. 20 of 2003 on National Education System), (b) recognition of professional and certified teacher (Law No. 14 the year 2005 on Teacher and Lecturer), (c) ) Autonomy of Education (including 20\% Education Financing Policy), and so on. But there are still many problems that need hard work to solve. One of the major issues in the field of management, in particular, is education management models, including school management. The most important quality of education issues include not only curriculum, learning process, evaluation, textbooks, teacher quality, facilities, but also management it self. Some very critical problems in the management field include (a) lacking in the education arrangements, (b) unclear in the education autonomy strategy, (c) slow and long bureaucracy, and (b) weak transparency of management.

During the new era of Suharto (1966-1998), the Education Management System in Indonesia had a very wide meaning. Education progress at that time, received recognition from around the world, especially the successful implementation of 12 -year basic education. But in the midst of success, there were still many problems to be resolved, such as unemployed educated people, which were also the result of the education system. On the one hand, education resulted in a large number of higher education graduates, but on the other hand, unemployment is also increasing. As explained by H.A.R Tilaar, that in the education system at least contains the cost factors, managers, institutions, and management system. The educational management system in the Suharto's era was too 
centralistic and bureaucratic, so the space for innovation was very limited. Similarly, the creativity of the educators was almost lost. This is because everything has been fully regulated and determined by the central government.

In the reformation era (since 1998-now), it began to emerge School Based Management (SBM) along with the rolling of regional autonomy. The concept of SBM was a great strategy to achieve effective and efficient school management. This SBM model is an idea where the decision-making power related to education is placed in the closest place to the teaching-learning process, i.e. the school. This concept is based on "Self Determination Theory" which states, among others, that schools have the power to make their own decisions. The Implementation of SBM brings a polarizing effect, such as the emergence of exclusive schools, prominent schools, expensive schools, schools with activities that end up burdening students and parents excessively. In addition, competition between schools, competition between students, and competition between parents also occurred. Competition on the pretext of fighting for a place in the school on behalf of the overseas exclusivity, excellence, and overseas brand offered by the school. Meanwhile, students remain subjected to objects, which were the objects to be shaped into superior human beings, competent human beings, powerful human beings, etc., without giving them adequate space to grow harmoniously within the family, community, and school environment. That was the school that put forward the souls of their ancestors and their respective cultures. In this case, a school was no longer a place for complete moral and intellectual development but is torn and trapped only in a narrow intra-curricular or extra-curricular scheme. The school was no longer a place for "among and pamong " cultural values that give the character of honesty, friendship, tolerance, diversity, recognition, noble values award, but it limited to a tense competition, contest and academic competition, such as the Olympics, Academic competitions, etc. This is aggravated by the incessant information technology and social media that can be accessed easily, which becomes uncontrollable. The school is powerless against this technological advancement, nor is it capable of using it well. It let alone protecting students from a rush of technology and social media. "Protecting" means taking positive and preventing negativity. This is a real big problem because the school must be able to come to be a protective body of students. The school must be able to provide a place for students to grow completely and protect them from a negative influence.

However, it should be emphasized that theoretically, the management system found by Western Author, such as the SBM model through the Planning, Organizing, Actuating, and Control (POAC) strategy may be extraordinary, but when it is applied in Indonesia, then the results seem not satisfied.

The question arises, why the western management theory that works well and successful in the origin country, but not necessarily successful Indonesia. Is the answer related to the value and cultural factor it self? Based on this, we need to examine the factors and rules of local wisdom and culture. In this article, the significance of Balinese local wisdom in developing school management model was analyzed.

\section{B. Adopting Balinese Local Wisdom in Developing School Management Model}

School management not only covers the management aspects of 8 education standards, as mandated by SISDIKNAS Number 20/2003 [4], such as Competency Standard, Content Standard, Process Standard, Teacher Standard, Facilities Standard, Management Standard, Financing Standard and Assessment Standard, but equally important is the value system that frames the 8-standard. For example, what is the meaning of intelligent learners, and have passed national assessment standard, if, in the end, they do not have honesty, tolerance, and the spirit of love for the homeland? Similarly, what does it mean, if a teacher has complied with the national standards, but has no commitment to lifelong learning, and makes his profession a sense of honor, as a teacher who becomes a civil servant and father to all his students? There are many Indonesian valuable cultural values, which may be difficult to quantify in verbal language, but actually embodied in thoughts, words, and deeds descended into the Indonesian nation.

In this paper, the concept of Balinese Local Wisdom (BLW) will be studied and presented more explicitly. The critical question is, what kinds and to what extent can BLW be integrated into the context of developing a modern School Management Model?

BLW is part of Balinese culture and also directly related to Hinduism, certainly has its own peculiarities. Balinese culture that holds local wisdom not only in the form of thought (ratio), but also the taste, works, and art that is usually done in everyday life. The Balinese are bound by the value of Tri Kaya Parisudha ie the Three Sacred Things: Mind, Speech and Deeds. Balinese Local Wisdom is a local wisdom to be the center of the inner-born struggle for the salvation of life. It is translated in Dharma as a truth as well as a sacred mandate. So wisdom can be interpreted as a frame of action that contains self-control based on Dharma. A guide to action to bring people more peace, prosperity, and harmony in their life.

Mungmachon [16] formulates: "Local wisdom is the knowledge that discovered by the people through the accumulation of experiences in trials and integrated with the understanding of nature and culture". Local wisdom is dynamic by the function of created local wisdom and is connected to the global situation. The definition of local wisdom as such, at least implies some concepts, namely: (1) local wisdom is a long experience, which is precipitated, as a guide to one's behavior, (2) local wisdom can not be separated from the environment of the owner, (3) local wisdom is dynamic, flexible, open, and always adjust to the era. Such a concept also at the same time gives an idea that local wisdom is always associated with human life and the environment. 
Local wisdom emerges as a guardian or shield against global change that plagues human life. Wisdom is the process and product of human culture. Wisdom is used to survive. Balinese culture has a variety of local descendants that can be classified as local wisdom. This is in line with the idea of Geertz [17]: "Local wisdom is a part of culture". Local wisdom is a cultural element that is related to human resources, the source of culture, economic, security and laws. It can be viewed as a tradition that is related with farming activities, livestock, building house, etc.

Related to the global phenomenon, the world now is filled with climate change, gap, terrorism, corruption, war, social anomaly, economy, culture and so on. In the perspective of the Balinese (Hindu), this era is called KALIYUGA, the "age of contention" characterized by the waning of spiritual life, because the world is shackled and dominated by material life.

Wilasa [18] states that "human orientation is merely pleasure and satisfying sensual or kama (desire) appetite. If that is continued then the lust is like a fire doused with gas, will grow bigger and can destroy itself". In Sarasamuscaya chapter 16 (2001) it is mentioned that: the praised is karma (deeds). In fact, what makes a person good is good, and what makes him bad is bad. A person will be good only by doing good, and someone becomes papa (suffering) for doing evil. This local wisdom can be an inspiration, for humans to return to self-worth, and concentrate on good deeds, not on phenomena that tend to be materialistic.

Here are some experts whose perspectives of BLW that can be used as a foundation in Developing School Based Management (cited from [19])

a) Pedanda Gunung; Balinese culture is a religious culture: It reflects Balinese religious people who gave birth to a clean, holy and pure culture inspired by religious teachings sourced from the Vedas

b) Gunadha, Balinese local wisdom is a part of work culture: With work culture, everything done by Balinese man based on Hinduism produces various forms of cultural products

c) Adiputra, Balinese local wisdom is a part of the culture of thought: The disclosure of different ways of thinking in manifesting the prostration of God. Balinese man can produce various cultural products that almost always nuance Balinese culture based on Hindu religion.

d) Sudiatmaka, Balinese local wisdom is a part of the rational cultural application: In addition to being dogmatic, Balinese culture is also rational, thus giving birth to the application of rational culture

e) Sura, Balinese local wisdom is a part of an organizational culture: To sustain the growth of
Balinese culture, it takes the support from traditional Balinese organizations called desa adat (traditional villages), banjar adat (a small part of desa adat; one desa adat consist of many banjar adat), tempekan ( a small group of banjar adat, one banjar adat may consist of some tempekan) and others

f) Wiana, Balinese local wisdom is a part of the totality of Balinese culture: Based on the Vedas as the guides of the noble conscience will realize the things are good and positive, by making sacrifices of mutual respect between professions with each other, so the conscience reflects a great culture superb. So the behavior and the result of culture and its elements, raised as the local content of Balinese culture is the totality of Balinese culture.

g) G. Wirta, The Balinese local wisdom is a part of the religious culture of Tri Murti: The application of the Tri Murti (Brahma, Vishnu, and Shiva) concept is meant for all cultural creation (Brahma), to be preserved (Vishnu) well in order to create harmony. At one time cultural products must be changed or replaced or destroyed (Shiva) so that all cultural products still have a usefulness for human life.

h) H. Gorda, Balinese local wisdom is a part of a meta culture: The meta culture (having magical appeal) needs to be nurtured and developed among professionals. This will be maintained if it is based on the clarity of religious values.

Based on the above perspective, it can be developed some concepts of BLW that are very appropriate as a foundation in Developing School Based Management, as follows:

a) Pasraman Concept: This word is derived from the word "dormitory" (often written and read ashram) which means the place of the learning process or education. Pasraman school emphasizes selfdiscipline, develops noble character and diligent nature, hardworking, lust-prohibition and fondness to help others. The ashram school describes the close relationship between teachers (acarya) with their students, as in a family. Therefore, this system is also known by the name of the education system gurukula. Students live in pasraman with teachers as family members and teachers act as students' own parents. The process of education in pasraman from the past is still ongoing until now known also with other terms namely parampara, in Java and in Bali known as padepokan or aguron-guron.

b) Guru Concept: The Guru (Sanskrit) comes from two words namely gu and ru. Gu stands for the word gunatitha which means not bound by material (possessions). $\mathrm{Ru}$ stands for the word rupavarjitha which means being able to cross (change) others from 
the miserable ocean. From this sense, it can be deduced that the "teacher" is a duty or occupation that becomes obligation (geginan = Balinese language) which is done sincerely (unconditionally) to deliver or release man from misery (folly and poverty) to a happy life and prosperity.

c) Brahmacari Concept: It is the lifetime of every people who are used to study. Charge his/her self to spiritual maturity so that spiritual and physical maturity develops in balance and balance. When this is realized then the person will show a responsible attitude. That is, every thing he does must be accompanied by an attitude of accountability. This is an adult mental attitude. When a person is in the Brahmacari period, his heart must be more compelled to study as much as possible in accordance with the slogan "Youth is learning and struggling time". Not the youth is used only for fun and joy. As the saying goes the youths are the backbone of the nation. They should be able to make history and be able to make changes in the times. Everyone should try to get through the Brahmacari period by achieving its goals or ideals.

d) Catur Marga concept: It is the four ways of practicing Hinduism (Veda) in life and in society. In this case, it can be interpreted as four ways of building and applying knowledge in schools, families, and communities. Because of our state and our inner abilities are not all the same, then through this Catur Marga, we are advised to do as much as possible, according to ability.

e) Menyama Braya Concept: It is the ideal concept of community life in Bali as a philosophy of karma marga that comes from the cultural values and customs of Balinese people to live harmoniously. Harmony contains intimate meaning, peaceful and not hostile, likened to the life of a married couple in a harmonious and peaceful household.

f) Ngayah Concept: Ngayah (serve) is not a strange verb for Hindus in Bali, literally ngayah means [20]: doing a job without wages, doing volunteer activities based on encouragement to help or actively participate (1) religious-territorial obligations, especially Pura Kahyangan Tiga , (2) duties related to indigenous banjar sociocultural activities (traditional banjar). This concept is almost similar to the concept of gotong royong (mutual assistance) in the wider context of Indonesian culture.

g) Tat Twam Asi Concept: It is the Sanskrit sentence, literally, this phrase means "It is you" and can simply be extracted as a recognition and appreciation of diversity and tolerance. h) Karma Phala Concept: It derived from Sanskrit from the vein "Kr" which means making or doing. It can be concluded that karma pala means deed or behavior. Phala which means fruit or result. Karma phala law means a rule or punishment of results in an act. It can also be interpreted as an action-related causal law, that there is no good result, without good work.

\section{CONCLUSION}

In order to build a school as a place not only for developing intelligent students but also for developing cultural values that give the character of honesty, friendship, tolerance, diversity, recognition, noble values, some principles and concepts of Balinese local wisdom can be applied as a foundation of modern school management. The principles and concepts of Balinese local wisdom are part Balinese culture that rooted in Veda, the holy book of Hindu. Some of the concepts are:

a) school as pasraman, in which self-discipline, noble character, and diligent nature, hardworking, lustprohibition and fondness to help others are emphasized.

b) students as brachmacarian, who charge his/her self to spiritual maturity so that spiritual and physical maturity develops in balance and balance.

c) Teacher as Guru (gunatitha-rupavarjitha), who has a duty or occupation that becomes obligation which is done sincerely (unconditionally) to deliver or release man from misery (folly and poverty) to a happy life and prosperity.

d) Knowledge as Catur Marga, that is four ways of building and applying knowledge in school, family, and community.

e) Attitude as ngayah, doing learning activities based on encouragement to help or actively participate.

f) To learn and to live as tat wam asi, develop the recognition and appreciation of diversity and tolerance.

g) Learning outcome as karmaphala, as an action-related causal law, that there is no good result, without good work.

\section{REFERENCES}

[1] A. M. Veneman, 'UNICEF Annual Report 2006'. UNICEF, 2006.

[2] S. Dogan, 'Conflicts Management Model in School: A Mixed Design Study', J. Educ. Learn., vol. 5, no. 2, pp. 200-219, 2016.

[3] I Gusti Ngurah Agung Darmayuda, 'Menjemput Pemikiran Ki Hajar Dewantara | Suluh Bali', 2017.

[4] Pemerintah Republik Indonesia, 'Undang-undang Republik Indonesia nomor 20 tahun 2003 tentang sistem pendidikan nasional', 2003.

[5] Mendikbud, 'Permendikbud Tahun2015 Nomor 082.' 2015. 
[6] B. Creemers, 'Development of a theory on educational effectiveness: testing a multi-level multi-factor, contextual theory about education', Educ. Res. J., vol. 8, pp. 1-11, 1993.

[7] D. Reynolds, P. Sammons, and T. Townsend, 'Educational Effectiveness Research (EER)', State Art Rev., pp. 4-7, 2011.

[8] G. R. Thakur, 'A Study of Organizational Behavior of Colleges of Education of Maharashtra State.', Online Submiss., 2014.

[9] A. Ebadollah, 'Organizational culture and productivity', Procedia Soc. Behav. Sci., vol. 15, pp. 772-776, 2011.

[10] S. P. Robbins, Management, 3rd ed. Yogyakarta: Prentice-Hall International, 1991.

[11] J. Hill, R. Ottem, and J. DeRoche, 'Trends in Public and Private School Principal Demographics and Qualifications: 1987-88 to 201112. Stats in Brief. NCES 2016-189.', Natl. Cent. Educ. Stat., 2016.

[12] R. Deshpande and F. E. Webster, 'Organizational Culture and Marketing: Defining the Research Agenda', J. Mark., vol. 53, no. 1, p. 3, Jan. 1989.

[13] A.-H. Jamal, 'Leadership Styles and Value Systems of School Principals', Am. J. Educ. Res. Am. J. Educ. Res., vol. 2, no. 12, pp. 1267-1276, Jan. 2014.

[14] Y. C. Cheng, 'Profiles of Organizational Culture and Effective Schools*', Sch. Eff. Sch. Improv., Jul. 2006.

[15] M. A. Kraft, W. H. Marinell, and D. Yee, School Organizational Contexts, Teacher Turnover, and Student Achievement: Evidence from Panel Data. Society for Research on Educational Effectiveness, 2015.

[16] R. Mungmachon, 'Knowledge and Local Wisdom: Community Treasure', Int. J. Humanit. Soc. Sci., vol. 2, no. 13, 2012.

[17] C. Geertz, The_Interpretation of Cultures. NEW YORK: Basic Books, Inc., 1973.

[18] I. P. Wilasa, Pencerahan Umat Hindu. Singaraja: HPDI Kabupaten Buleleng, 2001

[19] I. M. Karda, Sistem Pendidikan Agama Hindu di Perguruan Tinggi. Surabaya: Penerbit Paramita, 2007.

[20] 'Pencarian Kamus - BASAbaliWiki', 2017. [Online]. Available: http://dictionary.basabali.org/Special:SearchWord/?word=Ngayah\&la nguage=ban. [Accessed: 11-Aug-2017]. 